\title{
KOMPETENSI GURU MI/SD DALAM PEMBELAJARAN SAINS BERBASIS PENDIDIKAN KARAKTER
}

\author{
Oleb: Athok Fu'adi*
}

Abstract

This article reviews the importance of the competency of Elementary School or Islamic Elementary School Teachers in instruction of science subject. Learning science of elementary school is different from that of secondary and high schools. An elementary school teacher, in teaching science, should master instruction and teaching of science as well as its assessment technique, so that the students can achieve a determined indicator.

From this article, it is found a conclusion that the standard of the successful teacher depends on the teacher's personality, the mastery of teaching method, the teacher's frequency and intensity of interaction with students and the mastery of instructional strategy.

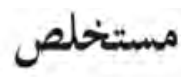

كدف الدراسة الحالية إلى استقصاء أهم الكفايات التي ينبغي توافرها لدى دعلم مادة العلوم في المدارس الابتدائية، سواء الحكومية منها أو الدينية. فتدريس العلوم في المرحلة الابتدائية، نظراً لعو امل شتى أهمها حداثة سن المتلقي، يفترض توافر معارف ومهارات خاصة لدى المعلم تختلف عن تلك الموجودة لدى المعلمين في المراحل التعليمية المتقدمة. لقد انتهت الدراسة إلى بناء مؤشر لكفايات المعلم المذكور يجوي أبعاد عديدة من أهمها: شخصية المعلم، تمكن المعلم من طريقة التدريس، كثرة وكثافة الأنشطة التفاعلية التي يجريها المعلم مع التالاميذ، إضافة إلى امتلاك المعلم لاستراتيجية واضحة لإدارة عملية التعلم.

Keywords: Kompetensi Guru, Pembelajaran Sains, Pendidikan Karakter

Dosen Jurusan Tarbiyah STAIN Ponorogo. Email: athokfuadi@yahoo.com 


\section{A. Pendahuluan}

Pendidikan Guru Madrasah Ibtidaiyah/Sekolah Dasar dewasa ini menjadi prioritas utama program pemerintah. Guru SD/MI yang memegang pendidikan sains kebanyakan bukan lulusan dari sains, maka muncul permasalahan di lapangan. Pembelajaran sains di Sekolah Dasar SD/MI dewasa ini belum selaras dengan tujuan pendidikan sains, masih berorientasi pada pendekatan isi (content). Pendekatan isi lebih menekankan pada penyiapan siswa untuk memasuki jenjang pendidikan yang lebih tinggi.

Pemberlakuan kurikulum KTSP saat ini, diorientasikan untuk menyiapkan siswa agar memiliki kompetensi dasar di setiap jenjang pendidikan sains. Sejalan dengan hal itu, pembelajaran sains hendaknya menekankan pada pengalaman secara langsung, yang bertujuan untuk mengembangkan sejumlah keterampilan proses dan sikap agar siswa mampu menjelajahi dan memahami alam sekitarnya.

Keterampilan proses ini, meliputi keterampilan mengamati dengan seluruh indera, mengajukan hipotesis, melakukan penyelidikan, menginterpretasikan temuan dan menarik kesimpulan, serta mengomunikasikan hasil temuan secara beragam, menggali dan memilah informasi faktual yang relevan untuk menguji gagasangagasan atau memecahkan masalah sehari-hari.

Mengingat pembelajaran sains diarahkan untuk membekali siswa dengan berbagai kemampuan tentang "cara mengetahui" dan "cara mengerjakan," maka model pembelajaran sains yang diterapkan selama ini, lebih menekankan pada aspek produk, tentu semakin tidak efektif. Keterampilan proses sains dalam hubungannya dengan pembelajaran sains dapat dinilai melalui pengamatan (observasi) aktivitas siswa dan dari pekerjaan siswa.

Oleh karena itu, diperlukan guru yang bisa memberdayakan siswa ke arah keterampilan proses sains dengan inquiry sehingga akan tercapai tujuan dari pembelajaran sains.

\section{B. Kajian Teori}

1. Kompetensi

Kompetensi adalah something that can be attributed to an individual on the basis of inferences drawn from performance in assessment or actual work. ${ }^{1}$

1 Gonczi Andrew, Developing a Competent Workforce, (NCVER: Adealide, Aus, 1992), hal. 225. 
Maksudnya, kompetensi adalah atribut seseorang yang dilihat dari (standar kompetensi) performa kerja orang tersebut. Kompetensi merupakan pengetahuan, keterampilan, dan nilai-nilai dasar yang merefleksikan dalam kebiasaan berpikir dan bertindak. ${ }^{2} \mathrm{Hal}$ tersebut menunjukkan bahwa kompetensi mencakup tugas, keterampilan, sikap dan apresiasi yang harus dimiliki oleh siswa untuk melaksanakan tugas-tugas pembelajaran sesuai dengan jenis tugas yang di milikinya.

Dilihat dari pendapat di atas, dapat disimpulkan bahwa kompetensi adalah suatu kemampuan, keterampilan dan sikap serta fitrah manusia yang terwujudkan dalam perilaku kognitif, afektif, dan psikomotor. Sehingga KTSP dapat diartikan sebagai konsep atau desain kurikulum yang dikembangkan berdasarkan seperangkat kompetensi tertentu sehingga hasilnya dapat dirasakan oleh peserta didik berupa penguasaan terhadap seperangkat kompetensi tertentu.

Sebagaimana disebutkan juga oleh Depdiknas bahwa KTSP merupakan seperangkat rencana dan pengaturan tentang kompetensi dan hasil belajar yang harus dicapai oleh siswa, penilaian, kegiatan pembelajaran dan pemberdayaan sumber daya pendidikan dalam pengembangan kurikulum. Pengembangan kompetensi dalam pembelajaran sains merupakan kompetensi yang berorientasi pada perilaku afektif dan psikomotor dengan dukungan pengetahuan kognitif dalam rangka memperkuat keimanan dan ketakwaan terhadap Tuhan Yang Maha Esa. ${ }^{3}$

Kemampuan kognitif berkaitan dengan kemampuan berpikir, yang mencakup kemampuan intelektual mulai dari kemampuan mengingat sampai dengan kemampuan memecahkan suatu masalah. ${ }^{4}$ Pada kemampuan kognitif siswa dilatih untuk memiliki kemampuan dan penguatan daya ingat, pemahaman dan penalaran dalam memecahkan suatu permasalahan atau mengembangkan ide baru. Kemampuan afektif berhubungan dengan perasaan, emosi, sistem nilai dan sikap hati yang menunjukkan penerimaan atau penolakan terhadap sesuatu. Sedangkan kemampuan psikomotor berkaitan dengan keterampilan motorik yang berhubungan dengan anggota tubuh atau tindakan yang memerlukan koordinasi antara syaraf dan otak, sehingga siswa

2 Depdiknas, Penilaian Berbasis Kelas, (Jakarta: Puskur Balitbang, 2002), hal. 13.

3 Depdiknas, KTSP, (Jakarta: BNSP, 2006), hal. 10.

4 Mukminan, Pembelajaran Tuntas (Mastery Learning), (Jakarta: Direktorat Lanjutan Pertama, 2003), hal. 6-8. 
diharapkan menirukan dan melakukan demonstrasi dan diharapkan mengetahui dan mengalami proses pembelajarannya sendiri.

Di samping itu, Gordon menjelaskan beberapa ranah yang terkandung dalam konsep kompetensi. Di antaranya adalah: 1) pengetahuan, yaitu kesadaran dalam kognitif; 2) pemahaman, yaitu kedalaman kognitif, afektif yang dimiliki oleh individu; 3) kemampuan, yaitu sesuatu yang dimiliki oleh individu untuk melakukan tugas atau pekerjaan yang diberikan kepadanya; 4) nilai, yaitu suatu standar perilaku yang telah diyakini dan secara psikologi telah menyatu dalam diri seseorang; 5) sikap, yaitu perasaan (senang dan tidak senang, suka atau tidak suka) atau reaksi terhadap suatu rangsangan yang datang dari luar; dan 6) minat, yaitu kecenderungan seseorang untuk melakukan sesuatu perbuatan. $^{5}$

Indikator pencapaian standar kompetensi diartikan sebagai kebulatan pengetahuan keterampilan, sikap dan tingkat penguasaan yang dicapai siswa dalam mempelajari mata pelajaran. Materi pokok atau materi pembelajaran adalah materi atau bahan kajian yang dapat berupa bidang ajar, metode, proses, keterampilan, konteks keilmuan suatu mata pelajaran. Sedangkan indikator pencapaian adalah kemampuan yang lebih spesifik yang dapat dijadikan ukuran untuk menilai keberhasilan belajar.

\section{Kompetensi Guru}

\section{a. Guru}

Guru adalah seseorang yang mempunyai kewajiban dalam membimbing dalam proses pembelajaran. Sebagai komponen yang sangat penting maka guru harus mempunyai kemampuan yang sesuai dengan fungsi dan tujuan sekolah. Mengetahui kondisi siswa adalah suatu keharusan bagi guru dalam pembelajaran. Oleh karena itu, guru diharapkan mengetahui materi pelajaran yang harus dipelajari dan didalami, dalam kondisi apa harus disajikan. Dengan demikian, guru dituntut untuk profesional dan mampu mengetahui apa yang merupakan kemajuan dalam diri siswa.

Guru yang baik harus lebih memahami berbagai masalah, lebih mengerti, lebih memiliki ilmu pengetahuan, lebih sempurna daripada 
orang-orang pada umumnya. ${ }^{6}$ Dalam kaitan tentang efektifitas keberhasilan guru menjalankan tugas kependidikannya, ada beberapa asumsi yang pada akhirnya menjadi titik tolak pengembangannya. Pertama, asumsi sukses guru tergantung pada kepribadiannya. Kedua, asumsi sukses guru tergantung pada penguasaan metode. Ketiga, asumsi sukses guru tergantung pada frekuensi dan intensitas aktivitas interaktif guru dengan siswa. Keempat, asumsi bahwa apapun dasar dan alasannya penampilan gurulah yang terpenting sebagai tanda memiliki wawasan, ada indikator menguasai materi, ada indikator menguasai strategi pembelajaran. ${ }^{7}$

Seorang guru harus memiliki kemampuan untuk melaksanankan tugasnya secara tepat dan bertanggung jawab. Jadi, kompetensi profesionalisme guru dapat diartikan sebagai kemampuan dan kewenangan guru dalam menjalankan profesi keguruannya, artinya, guru yang piawai dalam melakukan profesinya. ${ }^{8}$ Oleh karena itu, guru harus dapat menunjukkan kemampuan yang lebih baik dibanding dengan yang diajar, baik pada penguasaan keahliannya maupun pada metode dan strategi belajar mengajar yang dipilihnya. Guru harus senantiasa belajar dengan mengikuti perkembangan jaman. Dalam pembelajaran di sekolah pemilihan sumber daya guru harus dilakukan atas dasar kompetensi guru. Melihat semakin majunya kondisi sekarang ini, dibutuhkan penguasaan kemampuan yang lebih luas, kepribadian yang baik dengan diikuti kompetensi pada keilmuannya.

\section{b. Karakteristik Kompetensi Guru}

Raka Joni mengemukakan tiga kemampuan yang harus dimiliki oleh guru profesional. Ketiga kemampuan itu dikenal dengan tiga kompetensi. Pertama, kompetensi profesional. Maksudnya, kompetensi guru dalam memiliki pengetahuan yang luas serta dalam tentang subject matter (bidang studi) yang akan diajarkan kepada peserta didik, menguasai metodologi,

6 Gordon, Guru yang Efektif: Cara untuk. Mengatasi Kesulitan dalam Kelas, penyadur: Mudjito, (Jakarta: Rajawali, 1986), hal. 26.

Noeng Muhadjir, Ilmu Pendidikan dan Perubahan Sosial, suatu Teori Pendidikan. (Yogyakarta: Rake Sarasin, 1987), hal. 56.

8 Muhibbin, Psikologi Pendidikan: Dengan Pendekatan Baru, (Bandung: Remaja Rosdakarya, 1997), hal. 229. 
Dalam arti memiliki pengetahuan konsep teoritik, mampu memilih metode yang tepat, serta mampu menggunakannya dalam proses pembelajaran.

Kedua, kompetensi personal. Maksudnya, kompetensi guru dalam memiliki sikap dan kepribadian yang mantap, sehingga menjadi sumber intensifikasi bagi subjek. Guru harus memiliki kepribadian yang patut diteladani seperti yang dikemukaan oleh Ki Hajar Dewantara: ing ngarso sung tulodo, ing madya mangun karso, tut wuri handayani. Dalam proses pendidikan yang demokratis, guru berfungsi sebagai fasilitator dan motivator. Guru lebih banyak bersifat tut wuri handayani, dengan memberikan dorongan dan motivasi agar siswa dapat memperluas kemampuan pandangan untuk mengembangkan berbagai alternatif dalam aktivitas kehidupan.

Ketiga, kompetensi sosial. Artinya, guru harus memiliki kemampuan berkomunikasi sosial, baik dengan murid maupun dengan sesama rekan guru, kepala sekolah, karyawan, dan anggota masyarakat sekolah lainnya. ${ }^{9}$

\section{c. Pengembangan Kompetensi Guru}

Untuk meningkatkan kompetensinya, seorang guru harus selalu ingin belajar dan meningkatkan diri. Guru harus kompeten dan memiliki jiwa kader yang senantiasa bergairah dalam melaksanakan tugas profesionalnya secara inovatif. ${ }^{10}$ Guru yang aktif mengajar di sekolah selalu membutuhkan serta mencari tempat dan sarana untuk mengembangkan dirinya. Hal ini harus disesuaikan dengan karakteristik siswa, karakteristik materi, kondisi lingkungan, dan kondisi fasilitas. ${ }^{11}$

Melihat pendapat di atas maka seorang guru harus mempunyai kompetensi di bidangnya, meningkatkan kemampuan secara profesional, berusaha mengembangkan inovasi keilmuan dengan mencetak kader-kader pendidik. Dalam pengembangannya, guru harus menyesuaikan dengan kemampuan dan karakteristik siswa, serta lingkungan sekolah, sehingga tercapai yang menjadi tujuan dari sang guru.

Lembaga pendidikan yang mencetak tenaga kependidikan merupakan lembaga pendidikan guru pada tingkat universitas. Lembaga tersebut

9 Suharsimin Arikunto, Evaluasi Pendidikan, (Jakarta: Rineka Cipta, 1990), hal. 239.

10 Suyanto dkk., Wajah dan Dinamika Pendidikan Anak Bangsa, (Yogyakarta: Adicita Karya Nusa, 2001), hal. 136.

11 Zamroni, Paradigma Pendidikan Masa Depan, (Yogyakarta: BIGRAF Publising, 2000), hal. 65. 
mempunyai fungsi pokok dalam rangka mempersiapkan para calon guru baik SD/MI, SMP/MTs, MA/SMA, SMK, supaya kelak dapat melaksanakan tugas dengan sikap profesional sebagai guru.

\section{d. Profesionalisme Guru}

Seorang guru yang profesional harus bisa memberikan bekal pengetahuan secara kognitif, afektif, dan psikomotor. Pengetahuan kognitif merupakan pengetahuan yang ditransformasikan oleh guru kepada siswanya. Pengetahuan afektif adalah pengetahuan sikap yang ditanamkan oleh guru dalam pendidikan. Pengetahuan psikomotor berkenaan dengan keterampilan yang harus dikuasai oleh siswa dalam pembelajaran. Guru perlu mengetahui bahwa profesionalitas menekankan pada kemampuan berkreasi, produktif, dan pelestarian nilai-nilai universal. ${ }^{12}$

Pekerjaan yang bersifat khusus merupakan pekerjaan yang tidak dapat dikerjakan oleh sembarang orang, karena harus disiapkan secara khusus. Menurut Houton, beberapa persyaratan khusus yang harus dipenuhi dalam tugas profesional. Misalnya, dapat memenuhi kebutuhan sosial berdasarkan atas prinsip-prinsip ilmiah yang dapat diterima oleh masyarakat dan prinsip-prinsip itu telah benar-benar well-established; mengusai ilmu pengetahuan yang sistematik dan khusus (specialist) serta diperoleh melalui latihan kultural dan profesional yang cukup memadai; dapat membuktikan skill yang diperlukan masyarakat, di mana kebanyakan orang tidak memiliki skill, maksudnya skill yang sebagian merupakan pembawaan dan sebagian merupakan hasil belajar; memenuhi syarat-syarat penilaian terhadap penampilan dalam menjalankan tugas dilihat dari segi waktu bekerja; dapat mengembangkan teknik-teknik ilmiah dari segi pengalaman yang teruji, dan sebagainya.

Melihat pendapat diatas tentang berbagai ciri profesionalisme guru, dapat dikatakan bahwa seseorang yang profesional memiliki ilmu yang sesuai dengan kompetensinya. Mendapat kepercayaan dan tugas dari masyarakat, memiliki organisasi yang melindungi bidang kerjanya. Mempunyai kode etik bagi anggota profesinya, sehingga akan selalu menjaga kepercayaan dari masyarakat.

12 Noeng Muhadjir, Ilmu Pendidikan..., hal. 84. 


\section{e. Siswa}

Siswa adalah bagian terpenting dalam pembelajaran. Berbagai macam kegiatan diperlukan untuk pemenuhan kebutuhan siswa dalam belajar. Guru dalam penyampaian pembelajaran harus mampu mengetahui dan mengenal siswanya agar mampu memberikan pelayanan dan bimbingan dalam pembelajaran dan administrasi. Siswa akan bebas belajar jika hubungan dengan guru baik sehingga mereka tidak perlu lagi membuang waktu untuk membangun strategi menegakkan disiplin. ${ }^{13}$

Kurikulum harus lebih mendekatkan pada proses pengembangan kemampuan siswa. ${ }^{14}$ Pengembangan kurikulum dilakukan oleh guru-guru dengan melibatkan siswa. Isi dan proses pembelajaran dalam kurikulum selalu berubah sesuai dengan minat dan kebutuhan siswa. Pada dasarnya siswa dapat diklasifikasikan dalam tiga kelompok, yaitu normal, sedang dan tinggi.

Pengelompokan itu mengandung beberapa tujuan. Pertama, kelompok normal. Dalam kelompok ini tercakup makna mengembangkan pemahaman tentang prinsip dan praktikal aplikasi dan mengembangkan kemampuan praktikal akademik yang berhubungan dengan alam pekerjaan. Kedua, kelompok sedang. Cakupannya, mengembangkan kemahiran berkomunikasi, kemahiran menggali potensi diri, dan aplikasi praktikal serta mengembangkan kemahiran akademik dan kemahiran praktikal sehubungan dengan tuntutan dunia kerja ataupun untuk melanjutkan program pendidikan profesional. Ketiga, kelompok tinggi. Cakupannya, mengembangkan pemahaman tentang prinsip, teori, dan aplikasi serta mengembangkan kemampuan akademik untuk memasuki pendidikan tinggi. ${ }^{15}$

Melihat berbagai pendapat di atas, maka, seorang siswa memiliki perbedaan satu sama lain. Siswa berbeda dalam minat, kemampuan, kesenangan, pengalaman, dan cara belajar. Siswa tertentu lebih mudah belajar dengan mendengar dan membaca, siswa lain lebih mudah dengan melihat (visual) atau dengan cara gerak. Sehingga dalam pembelajaran semua

13 Gordon, Guru yang Efektif..., hal. 28.

14 Nana Syaodih, Pengembangan Kurikulum: Teori dan Praktek, (Bandung: Remaja Rosdakarya, 2004), hal. 11.

15 Depdiknas, Penilaian Berbasis Kelas..., hal. 9. 
komponen disesuaikan dengan karakteristik siswa. Dalam pengembangan pada diri siswa harus diketahui tingkat kebutuhannya, sehingga kecakapan yang dibutuhan siswa dapat diberikan sesuai dengan keinginannya.

\section{f. Materi Pelajaran}

Seorang guru harus benar-benar menguasai materi pelajaran yang diajarkannya. ${ }^{16}$ Beranjak dari pendapat tersebut maka seorang guru sains harus menguasai materi pelajaran yang disampaikan kepada siswanya. Guru yang baik harus mampu mencari metode yang tepat dalam menyajikan atau mengajarkan materi kepada siswanya dengan mempertimbangkan kemampuan anak didiknya, seperti menyajikan materi secara berurutan, dari yang mudah ke mudah, dari mudah ke agak sulit dan seterusnya.

Selain itu, guru menerangkan materi pelajarannya dengan menyenangkan. Cara penyampaian sumber belajar diharapkan dapat diterima dengan baik oleh siswa. Penggunaan sumber belajar yang dilakukan guru merupakan faktor yang ikut menentukan kesuksesannya dalam menyampaikan materi pelajaran. Materi yang diajarkan harus dengan berbagai macam variasi, harus diorganisasi dengan tiga tahapan pengorganisasian materi pembelajaran, yaitu perencanaan, pelaksanaan, dan penilaian.

\section{g. Mediator dan Fasilitator Murid}

Sebagai mediator guru pun menjadi perantara dalam hubungan antara siswa. Untuk keperluan itu, guru harus terampil mempergunakan pengetahuan tentang bagaimana orang berinteraksi dan berkomunikasi. Tujuannya ialah agar guru dapat menciptakan kualitas lingkungan interaktif secara maksimal. Secara maksimal, kualitas lingkungan yang interaktif meliputi tiga macam kegiatan yang dapat dilakukan oleh guru yaitu mendorong berlangsungnya tingkah laku sosial yang baik, mengembangkan gaya interaksi pribadi dan menambah hubungan yang positif dengan para siswa.

Sebagai fasilitator guru hendaknya mampu mengusahakan sumber belajar yang kiranya berguna serta dapat menunjang pencapaian tujuan

16 Purwanto, Kurikulum 2004: Pedoman pengembangan Penilaian, (Jakarta: Depdiknas, 2003), hal. 147. 
proses belajar mengajar baik yang berupa narasumber, buku ataupun surat kabar. Guru sebagai fasilitator adalah guru yang membantu anak didiknya dengan mengusahakan lingkungan belajar yang penuh dengan dialog yang mengarahkan siswa agar bisa mengutarakan semua pengalaman belajarnya sehingga dapat berkembang secara optimal. ${ }^{17}$ Mereka harus berusaha menuju pembelajaran yang bermakna sebagaimana dikemukakan oleh Rogers. Pembelajaran seperti itu terdiri dari lima unsur, yaitu: kualitas keterlibatan pribadi; prakarsa sendiri; adanya peresapan pengajaran; adanya evaluasi diri; dan adanya nilai, intisari yang bermakna.

Fasilator mesti menguasai berbagai bentuk komunikasi. Di antaranya, 1) mendengarkan secara pasif (diam). Dengan diam murid akan terdorong untuk meneruskan pembicaraan; 2) jawaban pengakuan, yaitu mengkomunikasikan jawaban sehingga menimbulkan suatu perhatian. Ini memberikan kesempatan pada murid untuk berkomunikasi lebih lanjut; 3) pembuka pintu, undangan untuk bicara untuk menunjukkan bahwa guru ingin mendengarkan dan meluangkan waktu; 4) mendengarkan secara aktif (umpan balik) untuk membuat murid merasa bahwa gagasan dan perasaannya dihargai, dipahami dan diterima. ${ }^{18}$

Guru sebagai fasilitator, maka semakin dituntut untuk menambah pengetahuan sesuai dengan perkembangan teknologi dan informasi. Kemajuan teknologi dan informasi tantangan bagi guru untuk mengarahkan siswa agar bisa mencapai tujuan pembelajaran, yaitu ketuntasan pembelajaran. Kemampuan mengondisikan kelas dan siswa dibutuhkan sebagai fasilitator, sehingga kemunikasi di kelas bisa berjalan dengan tertib dan dapat dinikmati siswa.

g. Lingkungan

Lingkungan meliputi lingkungan statis dan lingkungan dinamis. Lingkungan statis adalah keadaan bangunan dan alam sekitar, sedangkan lingkungan dinamis berarti lingkungan sosial dan lingkungan masyarakat. ${ }^{19}$ Di dalam lingkungan sekolah ada beberapa faktor yang mempengaruhi langsung proses pembelajaran di sekolah.

17 Achasius Kaber, Pengembangan Kurikulum, (Jakarta: Dirjen Dikti Depdikbud, 1988), hal. 194.

18 Gordon, Guru yang Efektif..., hal. 62.

19 Rumini, Psikologi Pendidikan, (Yogyakarta: UPP Universitas Negeri Yogyakarta, 2000), hal. 62. 
Faktor lingkungan sekolah yang kondusif akan dapat membantu mencapai sasaran yang diharapkan. Yang mewarnai penerimaan guru pada murid adalah lingkungan atau situasi sewaktu perilaku itu terjadi. Lingkungan belajar yang kondusif terwujud oleh semua komponen dalam proses pembelajaran di sekolah. ${ }^{20}$ Lingkungan belajar merupakan faktor eksternal yang dapat mempengaruhi perkembangan prestasi belajar siswa. ${ }^{21}$

Lingkungan sekolah merupakan segala sesuatu yang terdapat dalam lingkup sekolah dan mempengaruhi dalam proses pembelajaran, misalnya lingkungan fisik, sosial, keagamaan. Lingkungan sekolah harus dikelola dengan baik sehingga bisa mempengaruhi proses pembelajaran yang baik. Dengan pengelolaan yang baik, lingkungan akan bisa membawa pengaruh bagi pelaksanaan pembelajaran yang bersifat positif, aman dan agamis.

Selain lingkungan yang bersifat sosial, masih ada lingkungan yang sangat berpengaruh dengan proses pembelajaran, yaitu lingkungan yang rapi, aman dan terawat secara teratur, maka menyebabkan warga yang ada didalam lingkungan semakin senang. Dampak dari lingkungan yang rapi dan teratur, semakin meningkatnya prestasi siswa dan semakin bersemangat dalam mengejar kompetensi yang di targetkan.

\section{Pembelajaran Sains}

\section{a. Tujuan}

Mata Pelajaran IPA di SD/MI bertujuan agar peserta didik memiliki kemampuan sebagai berikut.

1). Memperoleh keyakinan terhadap kebesaran Tuhan Yang Maha Esa berdasarkan keberadaan, keindahan, dan keteraturan alam ciptaan-Nya.

2). Mengembangkan pengetahuan dan pemahaman konsep-konsep IPA yang bermanfaat dan dapat diterapkan dalam kehidupan sehari-hari.

3). Mengembangkan rasa ingin tahu, sikap positif dan kesadaran tentang adanya hubungan yang saling mempengaruhi antara IPA, lingkungan, teknologi dan masyarakat.

4). Mengembangkan keterampilan proses untuk menyelidiki alam sekitar, memecahkan masalah dan membuat keputusan. 
5). Meningkatkan kesadaran untuk berperan serta dalam memelihara, menjaga dan melestarikan lingkungan alam.

6). Meningkatkan kesadaran untuk menghargai alam dan segala keteraturannya sebagai salah satu ciptaan Tuhan.

7). Memperoleh bekal pengetahuan, konsep dan keterampilan IPA sebagai dasar untuk melanjutkan pendidikan ke SMP/MTs.

\section{b. Ruang Lingkup}

Ruang Lingkup bahan kajian IPA untuk SD/MI meliputi aspek-aspek berikut:

1). Makhluk hidup dan proses kehidupan, yaitu manusia, hewan, tumbuhan dan interaksinya dengan lingkungan, serta kesehatan.

2). Benda/materi, sifat-sifat dan kegunaannya meliputi cair, padat dan gas.

3). Energi dan perubahannya meliputi gaya, bunyi, panas, magnet, listrik, cahaya dan pesawat sederhana.

4). Bumi dan alam semesta meliputi tanah, bumi, tata surya, dan bendabenda langit lainnya.

\section{Pendidikan Karakter}

Pendidikan karakter adalah suatu usaha yang menyeluruh agar orangorang memahami, peduli, dan berperilaku sesuai nilai-nilai etika dasar. Dengan demikian objek dari pendidikan karakter adalah nilai. Nilai-nilai ini didapat melalui proses internalisasi dari apa yang diketahui, yang membutuhkan waktu sehingga terbentuklah pekerti yang baik sesuai dengan nilai yang ditanamkan. ${ }^{22}$

Pendidikan karakter, status moralitas individu mempunyai konsekuensi kelembagaan, tidak hanya tanggung jawab individu tapi juga memiliki dimensi sosial dan komunitas. Individu dan lembaga pendidikan memiliki tanggung jawab untuk menciptakan sebuah lingkungan moral yang mendukung pertumbuhan individu yang menjadi anggotanya. ${ }^{23}$

Ihwal pendidikan karakter Indonesia Heritage Foundation merumuskan sembilan karakter dasar yang menjadi tujuannya. Kesembilan karakter tersebut adalah cinta kepada Allah dan semesta beserta isinya; tanggung jawab, disiplin

22 Nurul Zuriah, Pendidikan Moral dan Budi Pekerti dalam Perspektif Perubahan, (Jakarta: Bumi Aksara, 1997), hal. 38.

23 Doni Koesoema A, Pendidikan Karakter, (Jakarta: Grasindo, 2007), hal. 198. 
dan mandiri; jujur; hormat dan santun; kasih sayang, peduli, dan kerja sama; percaya diri, kreatif, kerja keras dan pantang menyerah; keadilan dan kepemimpinan; baik dan rendah hati; toleransi, cinta damai dan persatuan. ${ }^{24}$

Jadi, menurut ketiga pendapat di atas pendidikan karakter adalah upaya penanaman nilai-nilai positif dalam diri individu yang berada di dalam komunitas. Hasil dari pendidikan karakter adalah suatu pertumbuhan nilainilai positif individu yang dapat diterima oleh komunitasnya. Pendidikan karakter melibatkan pendidikan moral dan pendidikan nilai.

\section{B. Pembahasan}

\section{Kompetensi Guru Sains Berbasis Pendidikan Karakter}

Pembelajaran sains tidak bisa terlepas dari latar belakang guru. Sebab, keberhasilan siswa tergantung pada kualitas pembelajaran yang dilakukan oleh guru tersebut. Kebanyakan guru yang mengajar sains SD/MI mempunyai latar belakang tidak sesuai dengan pendidikan sains. Hal ini dapat dilihat pada hasil observasi dari mahasiswa short course di Universitas Pendidikan Indonesia Bandung yang menyatakan bahwa kebanyakan guru yang mengajar ada yang masih kuliah, ada yang mengerjakan skripsi, ada juga karena bukan keahliannya. Hal ini menunjukkan bahwa kompetensi guru perlu ditinjau ulang lagi. Karena kompetensi adalah atribut seseorang yang dilihat dari performa kerja bagi seorang guru meliputi pengetahuan, keterampilan, dan nilai-nilai dasar yang merefleksikan dalam kebiasaan berpikir dan bertindak.

Guru mempunyai kewajiban dalam membimbing proses pembelajaran siswa. Sebagai komponen yang sangat penting, guru harus mempunyai kemampuan yang sesuai dengan fungsi dan tujuan pembelajaran. Hal ini didasarkan pada beberapa asumsi. Pertama, sukses guru tergantung pada kepribadiannya. Kedua, sukses guru tergantung pada penguasaan metode. Ketiga, sukses guru tergantung pada frekuensi dan intensitas aktivitas interaktif guru dengan siswa. Keempat, apapun dasar dan alasannya penampilan gurulah yang terpenting sebagai tanda memiliki wawasan, ada indikator menguasai materi, ada indikator menguasai strategi pembelajaran.

24 Ratna Megawangi, "Membangun SDM Indonesia Melalui Pendidikan Holistik Berbasis Karakter", dikutip dari www.keyanaku.blogspot.com accessed 24 Januari 2010. 
Kompetensi profesionalisme guru dapat diartikan sebagai kemampuan dan kewenangan guru dalam menjalankan profesi keguruannya. Artinya, guru yang piawai dalam melakukan profesinya. Oleh karena itu, guru harus dapat menunjukkan kemampuan yang lebih baik dibanding dengan yang diajar, baik pada penguasaan keahliannya maupun pada metode dan strategi belajar mengajar yang dipilih. Dalam pembelajaran di sekolah pemilihan sumber daya guru harus dilakukan atas dasar kompetensi guru.

Seorang guru yang profesional harus dapat memberikan bekal pengetahuan secara kognitif, afektif, dan psikomotorik. Pengetahuan kognitif merupakan pengetahuan yang ditransformasikan oleh guru kepada siswanya. Pengetahuan afektif adalah pengetahuan sikap yang ditanamkan oleh guru dalam pendidikan. Pengetahuan psikomotorik berkenaan dengan keterampilan yang harus dikuasai oleh siswa dalam pembelajaran.

Selain itu, guru dalam menerangkan materi pelajaran harus menyenangkan. Faktor yang menentukan kesuksesan seorang dalam menyampaikan materi pelajarannya karena ada perencanaan. Perencanaan terdiri dari per satuan waktu, per satuan bahan ajar. Perencanaan per satuan waktu terdiri dari program tahunan dan program semester/catur wulan. Perencanaan per satuan bahan ajar dibuat berdasarkan satu kebulatan bahan ajar yang dapat disampaikan dalam satu atau beberapa kali pertemuan. Pelaksanaan terdiri dari langkah-langkah pembelajaran di dalam atau di luar kelas, mulai dari pendahuluan, penyajian dan penutup. Penilaian merupakan proses yang dilakukan terus menerus sejak perencanaan, pelaksanaan dan setelah pelaksanaan pembelajaran per pertemuan, satuan bahan ajar, maupun satuan waktu.

Selain penguasaan perencanaan guru hendaknya memiliki pengetahuan dan pemahaman tentang media pembelajaran, karena media pembelajaran merupakan alat komunikasi untuk mengaktifkan proses pembelajaran. Media pembelajaran merupakan alat yang sangat diperlukan, bersifat melengkapi, bagian integral demi berlangsungnya proses pembelajaran di sekolah. Guru juga harus terampil menggunakan media pembelajaran, maka perlu pelatihan praktik yang sistemati, baik melalui pre-servise maupun inservise training. Sehingga guru menggunakan media pembelajaran sesuai dengan tujuan, metode, evaluasi, kemampuan guru serta minat, dan kemampuan siswa.

Sebagai mediator guru pun menjadi perantara dalam hubungan antar siswa. Untuk keperluan itu, guru harus terampil mempergunakan pengetahuan tentang 
bagaimana orang berinteraksi dan berkomunikasi. Tujuannya agar guru dapat menciptakan kualitas lingkungan interaktif secara maksimal. Secara maksimal, kualitas lingkungan yang interaktif meliputi tiga kegiatan yang dapat dilakukan oleh guru yaitu; mendorong berlangsungnya tingkah laku sosial yang baik, mengembangkan gaya interaksi pribadi, dan menambah hubungan yang positif dengan para siswa.

Sebagai fasilitator guru hendaknya mampu mengusahakan sumber belajar yang dapat menunjang pencapaian tujuan proses belajar mengajar baik, berupa narasumber, buku ataupun surat kabar. Guru sebagai fasilitator adalah guru yang membantu anak didiknya dengan mengusahakan lingkungan belajar yang penuh dengan dialog yang mengarahkan siswa agar bisa mengutarakan semua pengalaman belajarnya sehingga dapat berkembang secara optimal.

Guru semakin dituntut untuk mendapatkan pengetahuan dari waktu ke waktu yang semakin berkembang untuk memfasilitasi pengetahuan. Agar tercapai ketuntasan pembelajaran siswa. Kemampuan mengkondisikan kelas dan siswa dibutuhkan sebagai fasilitator, sehingga kemunikasi di kelas bisa berjalan dengan tertib dan dapat dinikmati siswa.

Selain kemampuan dan profesionalisme dia atas, guru sains dalam pembelajarannya harus menerapkan prinsip-prinsip pendidikan berbasis karakter, selain penguasaan dalam pembelajaran, karena pendidikan karakter sangat dibutuhkan oleh masyarakat dewasa ini. Sebenarnya pembelajaran sains sudah menerapkan ciri-ciri pendidikan berbasis karakter, karena di dalamnya ada pengetahuan, ilmiah, dan juga melakukan observasi. Pendidikan karakter bergerak dari knowing menuju doing atau acting.

William Kilpatrick menyebutkan salah satu penyebab ketidakmampuan seseorang berlaku baik meskipun telah memiliki pengetahuan tentang kebaikan itu (moral knowing) adalah karena tidak terlatih untuk melakukan kebaikan (moral doing). Berangkat dari pemikiran ini maka kesuksesan pendidikan karakter sangat bergantung pada ada tidaknya knowing, loving, dan doing atau acting dalam penyelenggaraan pendidikan karakter. Karakter tidak sebatas pengetahuan saja tapi menjangkau wilayah emosi dan kebiasaan diri. Jadi, untuk membentuk karakter yang baik harus terdapat tiga komponen karakter yaitu moral knowing (pengetahuan tentang moral), moral feeling (perasaan tentang moral), dan moral action (perbuatan moral). ${ }^{25}$

25 Lickona, T, “Reclaiming Children and Youth", Journal Winter, Vol.9, (Iss 4-2001), hal. 239. 
Untuk pembelajaran sains selain nilai-nilai ketiga di atas harus ada prinsip yang harus dikembangkan, yaitu tanggung jawab, kemampuan untuk merespons orang lain, memperhatikan orang lain, merespons secara aktif. Tanggung jawab berarti melakukan pekerjaan baik di rumah, di sekolah atau di tempat kerja sesuai dengan kemampuan yang dimiliki, sehingga siswa dapat melakukan tugas-tugas sains karena sains itu sendiri materinya banyak berkaitan dengan lingkungan dan juga makhluk hidup. Nilai moralitas lainnya adalah nilai kejujuran, toleransi, membantu, kerjasama, dan demokrasi. Kejujuran yang berhubungan dengan sikap menghargai orang lain berarti tidak menipu orang lain, tidak mencurangi, sehingga tugas yang dibebankan oleh guru dikerjakan dengan rasa jujur pada dirinya sendiri. Rasa toleransi juga mengekspresikan penghormatan seseorang terhadap orang lain. Toleransi adalah sikap yang obyektif dan fair terhadap orang lain yang mempunyai ide, ras, atau creed yang berbeda, sehingga siswa dapat menghargai hasil karya siswa lainnya, demikian juga dengan gurunya.

Penilaian keberhasilan pembelajaran sains berbasis pendidikan karakter dapat dilihat dari beberapa indikator. Pertama, nilai tanggung jawab dapat dinilai dengan kriteria kuantitas kehadiran siswa atau guru, banyaknya izin sakit atau izin yang lain, ketaatan terhadap peraturan bersama, kedisiplinan jam datang/pulang, kuantitas membolos, serta berbagai hal yang lain. Kedua, melihat jumlah siswa yang secara tepat waktu menyerahkan tugas, jumlah guru yang tepat waktu menyerahkan soalsoal atau daftar nilai ujian. Wali kelas atau guru hendaknya membuat catatan tentang keterlambatan atau ketepatan siswa menyerahkan tugas-tugas untuk menilai sejauh mana nilai-nilai tertentu telah dapat dihayati dan dilaksanakan oleh warga dari lingkungan sekolah. Ketiga, kegiatan menyangkut nilai kerjasama, saling menghormati dan nilai menghargai perbedaan dalam tugas pembelajaran sains. Keempat, melihat jumlah program-program dan kegiatan yang memiliki unsur kerja sama dengan sekolah lain dalam pembelajaran sains. Kelima, pendidikan karakter yang berhasil akan menciptakan suasana yang baik bagi proses pembelajaran. Jadi keberhasilan pendidikan karakter bisa dilihat dari prestasi akademis siswa. Keenam, penilaian nilai-nilai kejujuran dengan kriteria data siswa yang ketahuan mencontek ketika ulangan, maupun menyalin/menjiplak pekerjaan orang lain. Selain mengetahui langsung kejadian siswa yang curang, cara lain untuk menilai nilai-nilai kejujuran adalah dengan mengedarkan angket anonim tentang kualitas kejujuran, antar lain dengan menanyakan berapa kali dalam sebulan/ setahun siswa mencontek selama ulangan atau menjiplak pekerjaan rumah orang lain. 


\section{Kesimpulan}

Kompetensi guru MI/SD dalam pembelajaran sains berbasis pendidikan karakter harus diperhatikan oleh pemerintah, sehingga tujuan pembelajaran sains dapat tercapai. Guru harus mempunyai kompetensi yang berlatar belakang sains jika harus mengajar sains, karena ada beberapa hal yang tidak bisa dilakukan oleh orang lain atau guru lain, yaitu kemampuan untuk memunculkan rasa ingin tahu serta rasa inquiry. Dengan cara ini proses pembelajaran bisa berlangsung secara dinamis.

\section{DAFTAR PUSTAKA}

Arikunto, Suharsimi. 1990. Evaluasi Pendidikan. Jakarta: Rineka Cipta

Depdiknas. 2002. Penilaian Berbasis Kelas. Jakarta: Puskur Balitbang. . 2003. Kurikulum 2004: Pedoman Pengembangan Penilaian. Jakarta: Depdiknas. 2006. KTSP.Jakarta:BNSP.

Doni Koesoema A. 2007. Pendidikan Karakter. Jakarta: Grasindo.

Gonczi, Andrew. 1992. Developing a Competent Workforce. NCVER: Adealide, Aus Gordon, Thomas. 1986. Guru yang Efektif: Cara untuk Mengatasi Kesulitan dalam Kelas. (penyadur: Mudjito). Jakarta: Rajawali.

Harlen, W. 1992. The Teacbing of Science. London: David Fulton Publishers

Kaber, Achasius. 1988. Pengembangan Kurikulum. Jakarta: Dirjen Dikti Depdikbud. Lickona, T. 2001. "Reclaiming children and youth". Bloomington: Journal Winter .Vol.9, Iss. 4; pg. 239, 13 pgs

Megawangi, Ratna. 2006. "Membangun SDM Indonesia Melalui Pendidikan Holistik. Berbasis Karakter". dikutip dari www.keyanaku.blogspot.com. Accessed 24 Januari 2010.

Muhadjir, Noeng. 1987. Ilmu Pendidikan dan Perubahan Sosial, Suatu Teori Pendidikan. Yogyakarta: Rake Sarasin

Mukminan. 2003. Pembelajaran Tuntas (Mastery Learning). Jakarta: Direktorat Lanjutan Pertama. 
Mulyasa, E. 2003. Kurikulum Berbasis Kompetensi. Bandung: Rosdakarya.

- 2003. Menjadi Kepala Sekolah Profesional. Bandung: Rosdakarya.

Rumini, S. 2000. Psikologi Pendidikan. Yogyakarta: UPP Universitas Negeri Yogyakarta.

Sukmadinata, Nana Syaodih. 2004. Pengembangan Kurikulum: Teori dan Praktek. Bandung: Remaja Rosdakarya.

Suyanto \& Abbas. 2001. Wajah dan Dinamika Pendidikan Anak Bangsa. Yogyakarta: Adicita Karya Nusa.

Syah, Muhibbin. 1997. Psikologi Pendidikan: Dengan Pendekatan Baru. Bandung: Remaja Rosdakarya.

Zamroni. 2000. Paradigma Pendidikan Masa Depan. Yogyakarta: BIGRAF Publising. Zuriah, Nurul. 1997. Pendidikan Moral dan Budi Pekerti dalam Perspektif Perubahan. Jakarta: Bumi Aksara. 